\title{
Man or Myth? \\ The Retrieval of the True Chaikovsky ${ }^{1}$
}

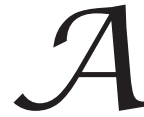

look at any CD catalogue or at the yearly plan of any symphony orchestra around the world will confirm the secure place of Chaikovsky's music in the repertoire. Conductors, instrumentalists, and singers, from his day to ours, have loved to perform his music. But the enthusiasm of the public and the performers has not yet been matched by a corresponding appreciation or even acceptance by his biographers, music critics, and other commentators. In what used to be the Soviet Union, compulsory nationalistic idolatry of Chaikovsky went hand in hand with a ban on all information about his personal life or his conservative political views. In the West, interest and enthusiasm have always been accompanied by critical incomprehension and hostility.

A comment by the venerable Eduard Hanslick at the time of the 1881 Vienna world premiere of Chaikovsky's Violin Concerto to the effect that this was music one "could hear emit a stench" is attributable to Western prejudice against Eastern Europe; people then could not quite believe that a Russian could produce a world-class masterpiece. But the contemptuous dismissal of Chaikovsky's music by such heavyweights of twentiethcentury musicology and criticism as Donald Francis Tovey, Paul Henry Lang and Edward Lockspeiser was due, as Richard Taruskin pointed out in a recent article, not to the quality of the music itself but to the critics' perception of the composer and his character. ${ }^{2}$

1 Review of Tchaikovsky: A Biographical and Critical Study, vol. 4, The Final Years, 18851893, by David Brown (New York: W. W. Norton, 1992); and Tchaikovsky: The Quest for the Inner Man, by Alexander Poznansky (New York: Schirmer, 1991). Originally published as "Man or Myth?: The Retrieval of the True Tchaikovksy [sic]" in Times Literary Supplement, 17 January 1992, 20-21.

2 The article referenced here is "Tchaikovsky, Fallen from Grace," New York Times, 30 June 1991; for a more comprehensive treatment of the same material, see R. Taruskin, "Pathetic Symphonist: Chaikovsky, Russia, Sexuality, and the Study of Music," New Republic, 6 February 1995; repr. with an update in Taruskin, On Russian Music (Berkeley: University of California Press, 2009), 76-104._Ed. 
As someone who considers Chaikovsky one of the great composers of all time and tries to read everything published about him, I was tremendously heartened by the appearance a few years ago of two studies of his music written by younger scholars: Tchaikovsky's Ballets by Roland J. Wiley and Tchaikovsky's Musical Style by Henry Zajaczkowski. ${ }^{3}$ Both authors demonstrated the freshness and originality of Chaikovsky's musical procedures, and Zajaczkowski, in particular, stressed the organic nature of Chaikovsky's handling of form, harmony, tonality, and orchestration. In neither book was there a trace of the squeamish distaste so usual in serious critical writing on this composer in English.

These two specialized studies stand in curious contrast to the three critical biographies produced in England over the past two decades. ${ }^{4}$ Of the latter, John Warrack's lavishly illustrated Tchaikovsky is an attractive, straightforward guide to the man and his music, treating both with fairness, but breaking no new ground and offering no new research. Edward Garden's Tchaikovsky reverts to the earlier pattern of incomprehension and hostility. Quite early in the book, the reader is informed that Chaikovsky's homosexuality meant that he was "unable to feel sexually aroused" and could not "establish a firm, constant and loving relationship with any other human being," and therefore suffered from "loneliness which was the lot in those days of the homosexual." Later in the book we read that "the frustrations of his endemic homosexuality" marred the music of Chaikovsky's Fourth Symphony and that his love life was either autoerotic or confined to homosexual fantasies. Chaikovsky's rich and rewarding love life and his sexual adventures are recorded in his published correspondence and in the diaries brought out by his brother Ippolit. ${ }^{5}$ But, like many others, Edward Garden was not interested in finding out about the real Pyotr Chaikovsky who lived from 1840 to 1893. He chose to depict, instead, the widespread popular myth of the lonely,

3 Roland John Wiley, Tchaikovsky's Ballets: Swan Lake, Sleeping Beauty, Nutcracker (Oxford: Oxford University Press, 1985); Henry Zajaczkowski, Tchaikovsky's Musical Style (Ann Arbor, MI: UMI Research, 1987).

4 John Warrack, Tchaikovsky (New York: Scribner's Sons, 1973); Edward Garden, Tchaikovsky (London: J. M. Dent, 1973); David Brown, Tchaikovsky: A Biographical and Critical Study, 4 vols. (New York: W. W. Norton, 1978-92).

5 Petr Chaikovskii, Dnevniki [Diaries], 1873-1891 (Moscow and Petrograd: Glavlit, 1923), published in English as The Diaries of Tchaikovsky, trans. Wladimir Lakond (New York: W. W. Norton, 1945). 
guilty, frustrated homosexual living out his life on the verge of a nervous breakdown or even insanity.

David Brown's four-volume Tchaikovsky: A Biographical and Critical Study began to appear in 1978 and is complete with the publication of its fourth volume. With its vast bulk, it is surely the most ambitious work on the subject ever undertaken. As a biographer, Brown amassed more information on Chaikovsky than any predecessor, and as a musicologist, he examined the composer's entire corpus. Because of the scope of the whole, each succeeding volume was hailed in the press of English-speaking countries as part of one of the greatest biographies of a cultural figure written in any language. Yet, now that all four volumes are available, I feel painfully disappointed. The understanding of Russian culture is often shaky, there is a poor grasp of the historical period, and Chaikovsky's individual qualities are barely perceptible.

Reviewing Brown's first volume in 1980, Malcolm Hamrick Brown expressed regret over the narrow range of biographical sources to which David Brown restricted himself. In this and in some other respects, David Brown shows himself to be a disciple of the Soviet music historian Aleksandra Orlova, whose help he acknowledges in the prefaces to each one of his volumes. In her writings on Chaikovsky published since her departure for the West in 1979 and especially in her sensationalist claims about the circumstances of the composer's death, Orlova limited her purview and manipulated the available evidence to foster her singular conception of the man and his music. In her view, Chaikovsky suffered all his life from being unable to overcome his homosexuality, a condition he regarded as "a curse laid on him by fate" and "a disgrace that could never be effaced." Much of his music is interpreted by Orlova as a sort of howl of despair caused by this ceaseless suffering.

Little of this is borne out by the composer's diaries or the memoirs about him, but David Brown must have found Orlova's interpretations congenial. In his first volume, he disqualified himself from "any deep elucidation of [Chaikovsky's] personality" on the grounds that he is "not a medical psychologist." But no medical qualifications were needed by the people who wrote successful biographies of Lytton Strachey, E. M. Forster, Somerset Maugham and other notable homosexuals-only a minimal understanding of what homosexuality is and how homosexuals fared in a particular culture during a given historical period. Instead of examining 
Chaikovsky's individual situation against the background of his society, Brown follows the examples of Edward Garden and Aleksandra Orlova and sets up the familiar anguished, suicidal homosexual figure of the popular myth. We read about the "growths of psychological abnormality which insidiously bound themselves round him, constricting, distorting and unbalancing his emotional life," thus making the composer unable to form "the closest of personal relationships." In his four volumes, Brown writes of a number of men with whom Chaikovsky formed relationships of precisely this kind. But the author's obvious distaste for the entire subject prevents him from recognizing them for what they were.

The epithets that most frequently occur in Brown's discussions of Chaikovsky's music are "flawed" and "second-rate." His enthusiasm is reserved for the composer's most acclaimed works: the Violin Concerto, the Sixth Symphony, the ballets, and the two most familiar operas, Evgeny Onegin and The Queen of Spades. Otherwise, some of Chaikovsky's most beautifully wrought scores receive either curt dismissals or ill-tempered scoldings. His lovely last opera, Iolanta, with its unique subject-a musical portrayal of blindness and of the trauma experienced upon gaining sight as an adult-is judged a failure, a "slender, pretty, but also insipid piece." The wonderful string sextet, "Souvenir de Florence," is proclaimed second-rate. The symphonic fantasy Francesca da Rimini is "flawed" because it is an expression of Chaikovsky's own "feelings of sexual guilt." (Ten pages earlier, Brown cited the composer's letter to his brother Modest where he maintained that he had never felt guilty for the way nature made him.) The Third Symphony, the finale of the Fourth, and the Second Piano Concerto ("irredeemably handicapped") are described in a tone of condescension shading off into contempt.

Of course, no composition by Chaikovsky is contemptible, not even the Piano Sonata, which receives a veritable tongue-lashing in Brown's book. Nor is it usual for biographers of composers who enjoy a worldwide fame to take such a jaundiced view of their subject and his oeuvre. The ultimate impression is that David Brown loves some of Chaikovsky's music, but detests his way of life to the point where his idea that the man is "flawed" spills over into the evaluation of his work. This would account for the continuous efforts to discredit the composer's less well-known works and to cast doubt on Chaikovsky's universally admired melodic inventiveness by either suggesting that the melodies are derivative (un- 
convincingly illustrated by musical citations from Berlioz, Beethoven, Glinka, etc., which Chaikovsky supposedly copied), or by finding in these melodies codes and ciphers that purportedly spell out names of people and places. Hugh Macdonald, a critic who seems to despise Chaikovsky ("a prancing pouf"), nevertheless published in 1983 a searching review of David Brown's second volume where he showed how arbitrary and unreliable this decoding of Chaikovsky's melodies is. ${ }^{6}$

After all the recent biographies that lack a minimal understanding of Chaikovsky's sexual orientation and reduce his life to stereotypes, the publication of Aleksandr Poznansky's Tchaikovsky: The Quest for the Inner Man comes like a fresh breeze through a stuffy room. ${ }^{7}$ For the first time since the appearance of Nina Berberova's biographie romancée in 1936 (it was reissued in French in 1987), Chaikovsky's story is told by someone who knows his period and his milieu intimately and has taken the trouble to understand his emotional experiences. Poznansky is not a musicologist but a social and cultural historian. The complaints by a few of the earlier reviewers of his book about the lack of musical analysis miss the whole point. No figure of comparable importance has had his biography and personality so utterly distorted by musicologists. It is the personal story of Chaikovsky, placed within the context of his time, that was desperately needed in English, and this is exactly what Poznansky provides. His is the first factually reliable literary portrait of this composer ever written and certainly a welcome one.

Poznansky draws on a larger body of source material than any other biographer-not only the censored and uncensored publications that appeared in Soviet times, but also a considerable body of prerevolutionary publications, such as the memoirs of Chaikovsky's wife, which Aleksandra Orlova (and, following her example, David Brown) did not bother to consult. We learn that certain character traits considered by some to be typically Russian, and by others as peculiarly Chaikovskian-sentimentality, melancholy, a penchant for weeping-were the result of his upbringing in the family headed by his father Ilya, a man who belonged

6 "Tchaikovsky: Crises and Contortions," review of Tchaikovsky, vol. 2, The Crisis Years, 1874-1878, by David Brown, Musical Times 124 (October 1983): 609, 611-12.

7 More recently Poznansky published a 2-volume biography of Chaikovsky in Russian: Aleksandr Poznanskii, Petr Chaikovskii: Biografiia (St. Petersburg: Vita nova, 2009).-Ed. 
in a sentimentalist novel of the end of the eighteenth century rather than in the second half of the nineteenth. Without any prejudice, Poznansky examines the various levels of the homosexual subculture that existed in Chaikovsky's time. As anyone who has studied that period in depth will know, there was an amazing degree of tolerance for homosexuality during the reigns of the last two tsars, something that can be verified by examining the lives of such contemporaries of Chaikovsky as the explorer Nikolai Przhevalsky, the poet Aleksei Apukhtin and the publisher Prince Vladimir Meshchersky. Many names that float barely identified through the other biographies-Nikolai Bochechkarov, Aleksei Sofronov, Iosif Kotek-acquire concrete reality as the composer's lovers or gay friends.

Poznansky's book easily disproves Aleksandra Orlova's story that the composer committed suicide by taking poison on the orders of a "court of honor" convoked by his one-time fellow students at the School of Jurisprudence. Where Orlova based her version exclusively on unverifiable, third-hand rumors and the testimony of people who never knew Chaikovsky, Poznansky, facts and historical evidence in hand, shows that this composer's death from cholera was one of the best-documented deaths on record and that because of a whole series of historical circumstances, the events described by Orlova could not possibly have happened.

The Chaikovsky portrayed in this biography is tremendously likeable: kindly, generous, cultivated and, quite often, happy. The book joins the musicological works of Wiley and Zajaczkowski as an instance of the new type of Chaikovsky studies: informed, imaginative, and treating both the man and his music with sympathy and respect.

Of course SK's review enraged David Brown and incited a blustery letter of protest to the editor of the TLS, which appeared in the issue of 7 February 1992. "I am honoured to find myself aligned beside 'such heavyweights' of musical criticism as Donald Francis Tovey and Paul Henry Lang," he began, as if oblivious to the invidious context in which those names had been invoked. He defended himself, together with Edward Garden, against the imputation of prudish hostility toward Chaikovsky with a well-aimed boomerang: "I think the trouble may be that we examine the evidence, then attempt to estab- 
lish the truth, rather than make up our minds what we want the truth to be, and then try to square the evidence with this." He attempted to laugh off Poznansky's book by quoting from a scurrilous review that matched his own prejudices. " "But what I simply cannot stomach," he finally confessed, "is to be found wanting beside a biographie romancée of Nina Berberova. How, sir, do you think H. C. Robbins Landon or Julian Budden would have felt if, say, Barbara Cartland had written a romantic biography of Haydn or Verdi, and their views of these composers had then been judged less perceptive than hers?"

Terrible, no doubt; but the analogy was shaky. Robbins Landon and Budden were, like Brown, authors of multivolume monographs. ${ }^{9}$ But placing himself on the level of these distinguished nonacademic writers was as big a blunder as was placing Nina Berberova, a major scholar as well as a romancière (and a writer with whom Dr. Brown was evidently unfamiliar), on a level with Barbara Cartland. SK was no Postmodernist à la Hayden White, ${ }^{10}$ but he did recognize (and, in this review, forcefully affirmed) the principle that knowledge of facts without precise knowledge of social context is as fatal to historiography as imagination without knowledge of social realities is to the writing of fiction.

8 Paul Griffiths, “Outing Peter Ilyich,” New York Times Book Review, 5 January 1992.

9 H. C. Robbins Landon, Haydn: Chronicle and Works, 5 vols. (London: Thames and Hudson, 1976-80); Julian Budden, The Operas of Verdi, 3 vols. (London: Cassell, 1973-81).

10 In, say, The Content of the Form: Narrative Discourse and Historical Representation (Baltimore: Johns Hopkins University Press, 1987), a study of figurative language in historical writing, which is often accused of attempting to erase the line between history and fiction. 